\title{
Local people's perceptions of climate change and related hazards in mountainous areas of northern Thailand
}

\author{
Sujata Manandhar ${ }^{\text {a, }}$, Weerayuth Pratoomchai ${ }^{a}$, Keisuke Ono ${ }^{\text {b }}$, So Kazama ${ }^{a}$, Daisuke Komori ${ }^{a}$ \\ ${ }^{a}$ Department of Civil Engineering, Tohoku University, 6-6-06, Aoba, Sendai 980-8579, Japan \\ ${ }^{\mathrm{b}}$ CTI Engineering Co., Ltd., 3-21-1 Nihonbashihamacho, Chuo ku, Tokyo 103-8430, Japan \\ *Email address: sujatamanandhar@gmail.com, sujata@kaigan.civil.tohoku.ac.jp \\ Tel/Fax: +81 (0) 227957455
}

\begin{abstract}
This study investigates the perceptions of local people on climate change and related hazards in Yang Luang Village (YLV), which is located in the mountainous region of the Mae Chaem basin in northern Thailand. Furthermore, this study examines the differences between the perceptions of local people and scientific observations in this area. Both quantitative and qualitative methods were used, and the data were collected from various sources. Results show that nearly $45 \%$ of households have personally perceived climate change, mainly in the form of increasing rainfall, decreasing number of rainy days in the last two decades and of extremely late rainfall in recent year's rainy season. A comparison of locals' perceptions and climatic observations shows that local people have correctly perceived rainfall changes, which have largely influenced the experiences and perceptions regarding climate-related hazards. More than $70 \%$ of households have perceived droughts and floods impacts on their livelihoods but have not completely understood their causes. They have correctly perceived the landslide resulted from increasing amounts of rainfall. However, they are unaware of increasing landslide trends, flood hazards and the associated potential risks. The results are helpful to assess the needs in terms of actions and information to facilitate climate-related hazard management at the local level in Thailand. Hazard awareness campaign, training and early warning system are necessary for breaking the low perception of potential hazards in YLV. Moreover, a hazard management strategy without waiting for proof of a trend coming from reviews of the climate science is essential.
\end{abstract}

Key words: Drought; Flooding; Hazards; Landslide; Mae Chaem; Perception

\section{Introduction}

Climate change is a reality, and it is occurring at an unprecedented rate [1,2]. Scientific evidence indicates that climate changes, mainly rainfall changes, are increasing the risk of extreme climatic events (such as droughts and floods) and the compounding of events (for example, heavy rain leading to landslides and soil erosion) around the world [3]. When such events can adversely affect elements of human systems, they assume the characteristics of a hazard. Moreover, the Intergovernmental Panel on Climate Change (IPCC) demonstrated a medium confidence that droughts and floods would intensify in the $21^{\text {st }}$ century due to reduced rainfall and/or increased evapotranspiration and heavy rainfall, respectively, during some seasons and in some regions. Regarding landslide, it is very likely that heavy rainfall will affect landslide in some regions around the world. For example, an increase in total rainfall or an increase in the frequency or magnitude of severe rainstorms $\left(>100 \mathrm{~mm} \mathrm{~h}^{-1}\right)$ could cause more frequent debris flows by mobilizing unconsolidated, regolith and by raising pore water pressures [3]. It could lead to deep-seated slope failure in the Caribbean, Central America, Europe, Indonesia, the Philippines, and Japan [4, 3], and slope instability and shallow landslides in Thailand [5]. The above climate-related hazards may result in immense and long-lasting impacts on the livelihoods of individuals, communities, and the environment.

Southeast Asian countries such as Thailand are already experiencing climate change and an increasing frequency of climate-related hazards, such as droughts, floods and landslides, which have resulted in substantial impacts in many areas $[6,7,8]$. The mountainous area of northern Thailand is not exempt from these hazards. Among others, the landslide events that occurred in Wang Chin (2001), Mae Chaem (2002), Maeramad (2004), Lablae (2006), and Si Satchanalai (2006) claimed many lives, destroyed many houses and resulted in severe economic losses [9, 10, 11]. The Thai Meteorological Department (TMD) [12] reported that Thailand (including the northern mountainous areas) faced the impacts of drought in 1967, 1968, 1977, 1979, 1986, 1987, 1990, 1991, 1992, and 1993. Furthermore, the greatest flood recorded in Thailand struck the Chao Phraya Basin (CPB) in 2011 and caused tremendous damage in northern and central Thailand, resulting in more than 800 casualties and approximately 35 billion US $\$$ in losses [13]. Because climate change is a trigger for extreme rainfall events and related hazards, obvious concern exists regarding how climate change will influence hazards in the future. In this 
regard, the latest flood that occurred in 2011 in the CPB alerted scientific communities. Consequently, several climate change projection and impact assessment studies have been conducted. For example, studies were conducted by Champathong et al. [14] and Kotsuki et al. [15]. These studies have provided a wealth of information regarding future climate change and its potential impacts on water resources in the CPB. However, on its own, such information cannot provide conclusive information for improving hazard management and decision-making at a local level. Climate change, related hazards, and their impacts will most likely be regionally and locally uneven [16]. Moreover, climate extremes are rare and interact with more local (physiographic) factors. Thus, each single event (hazard) tends to have a unique character [17]. To develop appropriate policies and responses, it is important to anticipate the nature of expected changes and to understand how climate change and its related hazards are perceived, experienced and interpreted by local people [18].

Local people live close to nature and build up an intimate and intuitive understanding of the environment over long periods of time. Local perceptions of climate change derive from daily interactions with the environment and dependence on weather conditions to ensure sustenance [19]. Therefore, the perceptions of local people can reflect local issues [20]. In addition, these perceptions reveal the actual impacts of climate change and its related hazards on the lives of people, especially for local factors that cannot be easily estimated through models. Therefore, this study aims to provide insights regarding the perceptions of local people toward climate change and its related hazards at the ground level in the mountainous areas of northern Thailand. However, in some instances, there is a possibility of misleading personal experience or misperception leading to risks of hazards being misjudged. For example a perception study conducted in riverside urban areas of Hanoi revealed that local community have not perceived the risk of catastrophic flood event needed for effective policy implementation despite regular flood experiences. Moreover, the scientific observation showed a possible increase in rainfall magnitude, frequency and higher chances of future catastrophic floods in that area. A difference between the local perceptions and scientific observations informed the need to educate the community leaders and community for disseminating right information to help community gain appropriate perception of flood risk [21]. Likewise, Bradford et al. [22] also compared local perceptions to scientific observations. It helped to identify key issues pertaining to the role of public perception and awareness in flood risk management and make recommendations to improve the social dimension of flood risk management plans in Europe. Investigating local perceptions and gap between perceptions and observations is found highly relevant in hazard management and decision making. Furthermore, this study aims to examine the differences between the ground experiences (local people's perceptions) and scientific observations of climate change and its related hazards by comparing available physical datasets or their derivatives (scientific literature). For this purpose, Yang Luang Village (YLV), which is located in the mountainous Mae Raek Basin (MRB), a sub-basin of the Mae Chaem Basin (MCB) in the Upper Chao Phraya Basin (UCPB) of northern Thailand (Fig. 1a, 1b, 1c), was selected as the study area. This study contributes to the local knowledge of climate change and its related hazards in Thailand. Furthermore, it helps identify the needs in terms of actions and information to give, which reduce the effect of potential natural hazards in the mountainous areas of northern Thailand.

\section{Methodology}

\subsection{Study area}

The YLV lies $5 \mathrm{~km}$ west of Mae Chaem city in the MRB (Fig. 1b, 1c). Many villages in northern Thailand have suffered from different climate-related hazards, such as droughts, floods and landslides. However, YLV has suffered from all three hazards, with the most serious of these hazards including a landslide in 2002, flooding in 2011 and drought in 2012. Approximately 900 people live in YLV and agriculture is their main source of livelihood. Climate change, mainly rainfall change and drought, has direct impacts on rainfall dependent agricultural livelihoods. Local people's experiences of various climate-related hazards strongly influence their perceptions, which is very important to be studied for hazard management. Thus, YLV is a relevant and interesting example for studying the perceptions of climate change and its related hazards at a local scale and at one location. The YLV is situated at the confluence of the Mae Raek River (MRR) and the Mae Chaem River (MCR) (Fig. 1c), with an altitude of 258 to approximately 700 meters above sea level and a monsoonal climate. The YLV receives approximately 1060 millimeters $(\mathrm{mm})$ of annual rainfall (as of 2008), with approximately $70 \%$ of the rainfall occurring during May to October (rainy season). The months of November through April are generally dry. Furthermore, approximately 900 people live in YLV and their main source of livelihood is agriculture. These people generally use a rice cultivation system that is supplemented with vegetables and soybeans in the lower irrigated areas and corn in upper hilly areas. Commercial livestock farming is absent in the area. In addition to farming, many individuals work as agricultural laborers. Most of the agriculture is 


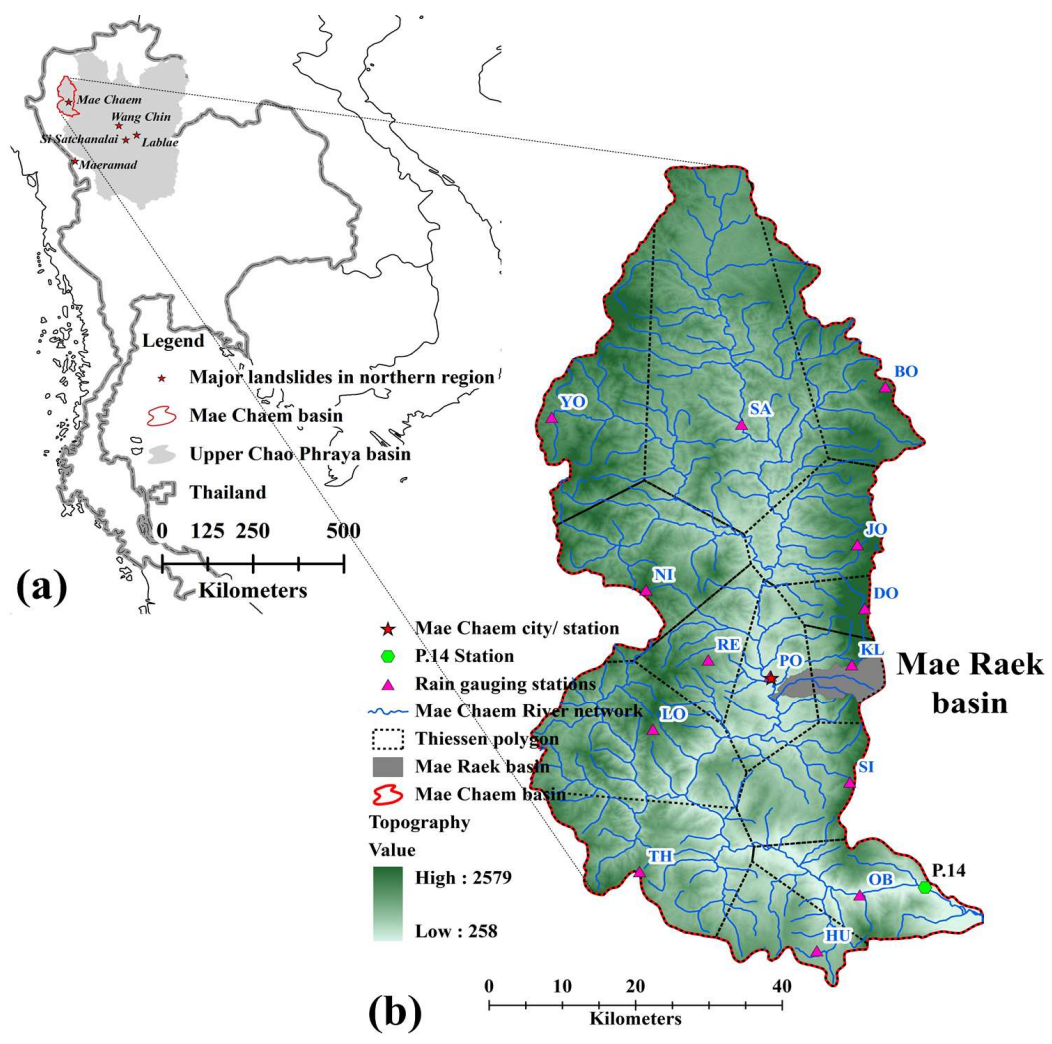

Fig. 1. Upper Chao Phraya Basin and the locations of landslide events (a), Mae Chaem Basin (b) including hydrometeorological stations

(Note: YO- Mae Yod, SA- Mae Sa, BO- Bo Kaeo, NI- Mae Ning, JO- Mae Jon Luang, DO- Doi Inthanon, RE- Research Station, PO- Pou, KL- Mae Klang, LO- Mae Long, SI- Sirikit Plantation, TH- Mae Tho, OBOb Luang, and HU- Huay Bong rainfall gauging station)

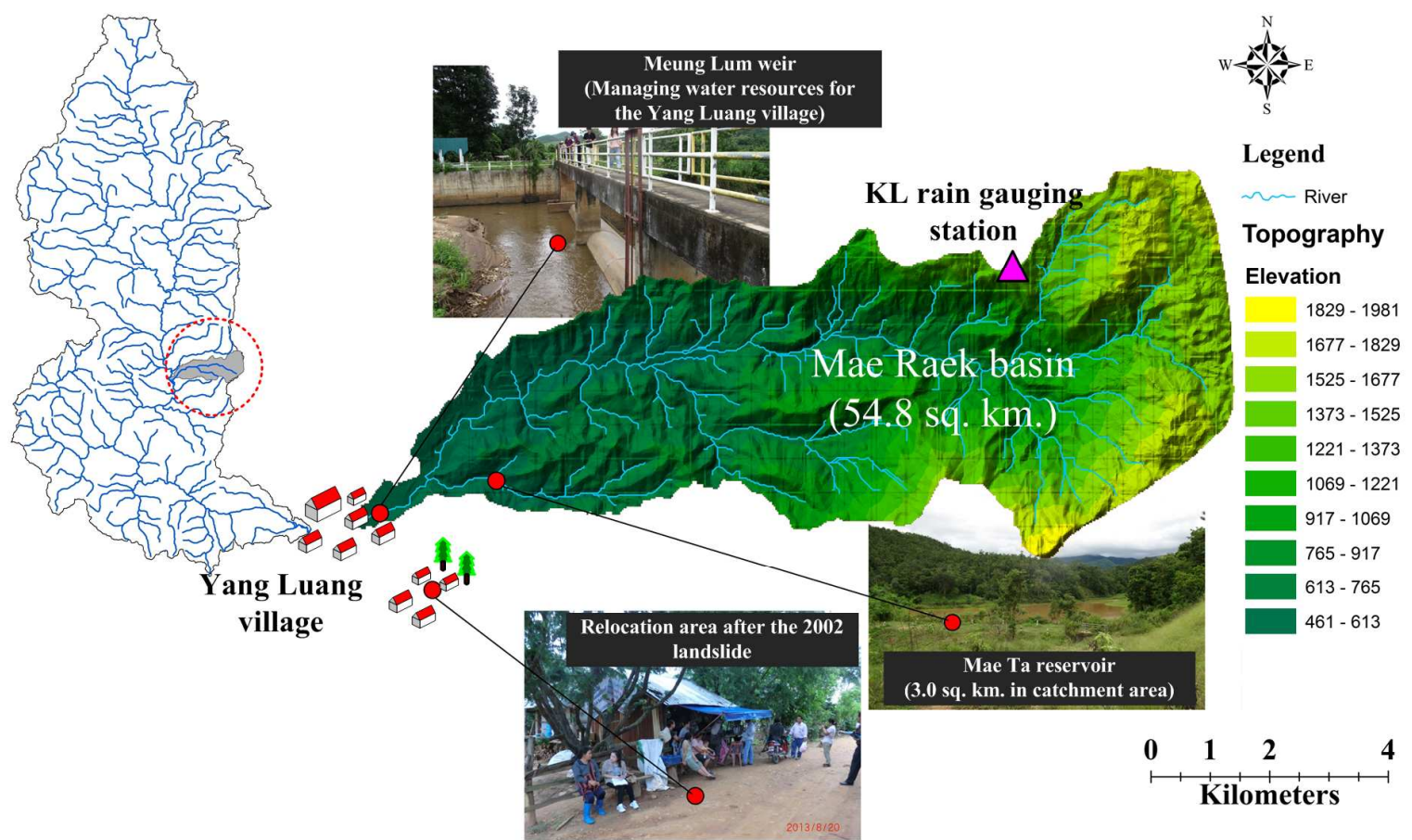

Fig. 1c. Yang Luang village in Mae Raek Basin (Note: KL- Mae Klang rainfall gauging station) 
rain-fed, and only a limited area has irrigation facilities. Irrigation water is managed from the MRR through a community managed irrigation system and a small (Mae Ta) reservoir (constructed by Thai government and later also managed by local community). Pipe-water, ground water, rainwater and bottled water purchased from the market are the main sources of domestic and drinking water. In general, this village has access to basic infrastructures, such as water supply, roads, and electricity. The most common education level is elementary. The average household size of YLV is 3.6, and the average monthly household income is approximately 150 US\$.

\subsection{Data collection}

Data were collected from primary and secondary sources. Qualitative (field observation) and quantitative participatory approaches (household questionnaire survey) that were frequently used in earlier perception studies [23, 24] were used for the primary data collection in August 2013. The questionnaire was designed with three sections (general information, perception of climate change, and perceptions of climate-related hazards) and 48 open- and close-ended questions based on earlier studies [25, 26, 27] (see Appendix-A). For this household questionnaire survey, a simple random-sampling technique was used when choosing the households. We visited from house to house randomly and they were only surveyed if the respondents were older than 35 years. The age criterion was used because young respondents would not have enough years of experience to properly distinguish climate changes [23]. Overall, 87 of the 227 households were surveyed. The sample size was calculated at a $90 \%$ confidence level based on the method given by Gautam and Shivakoti [28]. All respondents and households were native Thai speakers. Thus, the questionnaire was used in the native Thai language. Several additional households were surveyed to provide a margin of safety in case certain household surveys were unusable due to many unanswered questions. Each household interview took approximately 45 to 60 minutes. Secondary data (scientific observations or hydro-climatic data and relevant literature) were collected from various sources. Secondary data, such as the daily rainfall recorded at various stations in the UCPB and MCB and the daily river discharge recorded at the P.14 station (refer Fig. 1b), were collected from the University of Tokyo's data archive [29] and the Royal Irrigation Department of Thailand (RID) [30].

\subsection{Data analysis}

\subsubsection{Household data analysis}

The surveyed data were entered in a Microsoft Excel-2007 database and imported into the IBM SPSS Statistics 21 software for analysis. Households with missing data were omitted based on a simple listwise deletion approach [31]. In addition to simple descriptive statistics, Fisher's exact test and a multinomial logistic regression test were applied for data analyses to better understanding the collected data. Detailed descriptions of the Fisher's exact test and the multinomial logistic regression are provided in Appendix-B. Brouder and Lundmark [32] and Gebrehiwot and Veen [33] used similar statistical tests in earlier perception studies. The choice of the explanatory independent variables for the multinomial logistic regression was based on the data availability and the literature. In previous research, it was observed that household and climate attributes influenced the perceptions of the local people regarding climate change and its related hazards [23,34]. For example, high education indicates that the population has a better ability to read and understand climate change and related hazard issues from various sources [35], and the individuals perceiving increases in rainfall and rainfall variability are more aware of climate change and the related hazards (e.g., flood) [36, 26]. Based on previous literature, our null hypothesis was that a range of household and climate attribute variations would not influence people's perceptions of climate change and the related hazards. If the Fisher's exact test showed a significant result at the 5\% significance level $(p \leq 0.05)$, the null hypothesis was rejected. Later, the results of the people's perceptions were compared to hydro-climatic data analysis results to examine the differences between the ground experience and the scientific observations of climate change and the related hazards.

\subsubsection{Hydro-climatic data analysis}

Climatic data analysis: The Mae Klang (KL) station in the MRB (see Fig. 1c) has only collected 6 years of rainfall data. Therefore, 30 years (1982-2011) of data from the Mae Chaem station (located near the study village and outside of the MRB) were analyzed to determine the long-term rainfall changes. However, data from the KL station was also supportive for studying the rainfall changes in the YLV between 1998 and 2003. Furthermore, rainfall data from the Wang Chin (2001), Maeramad (2004), Lablae (2006), and Si Satchanalai (2006) stations in the 
UCPB (see Fig. 1a) were analyzed to assess extreme rainfall (amount) that caused landslides in different locations. Descriptive statistics, such as sum and frequency, were used to analyze changes in the long-term annual rainfall, accumulated monthly rainfall, total rainfall during the peak rainy months (August, September, and October), and the number of rainy days. Additionally, the Standardized Precipitation Index (SPI) (given by McKee et al. [37]) was calculated for 1, 2, 3, 4 and 6-month time scales to assess the dry (drought) and wet (flood) conditions in the study area. The SPI is a normalized index that represents the probability of the occurrence of a specified amount of observed rainfall when compared with the rainfall climatology at a certain geographical location over a long-term reference period. The index value is negative for dry conditions and positive for wet conditions. For studying the temperature changes, the data analysis results published by TMD [38] were used in this study.

Hydrological/discharge data analysis: Discharge data were only available for the gauging station (P.14) at the outlet of the MCB (see Fig. 1b). Therefore, the discharge data at the outlet of the MRB were synthesized using the tank model given by Sugawara [39]. This model is a conceptual lumped rainfall-runoff model with a simple structure and easily calculates and reproduces hydrographs [40 and 41]. In addition to discharge data, rainfall data from various stations (as shown in Fig. 1b) were used as model inputs. The model was calibrated and validated from 2000 to 2003 for the entire MCB. Next, the parameter values were transferred to synthesize the discharge for the MRB. A hydrograph was plotted to evaluate the high flows (flood) in the MRB. Details regarding the model description, parameters, calibration and validation (results) are provided in Appendix-C.

\section{Results and discussion}

In this section, the results are discussed in the following order- (i) perceptions of the local people regarding climate change; (ii) scientific observations of climate change; (iii) perceptions of the local people regarding climaterelated hazards and (iv) scientific observations of climate-related hazards.

\subsection{Perceptions of the local people regarding climate change}

Approximately $45 \%$ of the surveyed households have perceived climate change personally. These perceptions occurred because agricultural livelihood is dependent on the weather; thus, it is important for farmers to pay attention to local weather and climate variations. Additionally, $47 \%$ of others have heard about climate change from various sources (e.g., mass media or communication with neighbors). This finding provides evidence that access to information on climate change is an important factor that influences the likelihood of local people taking adaptation measures. Fisher's exact tests performed between the different household variables and climate change perception did not show any significant results (i.e., $p>0.05$ ) (Table 1). Thus, no differences in climate change perception occurred between households belonging to different household variable categories. Irrespective of gender, age, education and income source, $92 \%$ of the households had perceived climate change. A greater proportion of the households (49\%) had experienced significant changes in climate in the last 15 to 20 years. In addition, the fisher's exact test did not show any significant differences in climate change perception between the households with less than or equal to 30 years and more than 30 years of farming experience (see Table 1). This complements the local people's perceptions of changes that have occurred in the last two decades. $42 \%$ of households believed climate change, especially rainfall change, is resulted from human activities, such as deforestation. Regardless of whether this link exists, households have identified this as a source of concern and many of the perceptions of the households regarding climate change were strongly tied to their observations of this pattern.

More than 60 and $80 \%$ of households have perceived increases in the amount of rainfall and decreases in the number of rainy days in the last two decades, respectively. Moreover, $86 \%$ of these households have noted that rains previously began in mid-April, but now begin later in the middle of May or June. Extreme rainfall delays in 2010 and 2011 have largely influenced the local people's perceptions of changes in rainfall timing. The Fisher's exact test that was performed to determine the relationship between the local people's perception of climate change and the changes in climate variables showed significant results $(p=0.006)$ for changes in rainfall timing (see Table 1$)$. To understand why local people are concerned about rainfall delays, it is important to recognize their needs in terms of rainfall [42]. Agriculture is the main source of livelihood for residents in YLV, with approximately $75 \%$ of households having loans from a local bank. Only $16 \%$ of these residents have irrigation facilities. The remaining households depend on rainfall. Delays in rainfall result in production losses, with income losses, delayed payment of existing loans and the addition of extra loans. Thus, $74 \%$ of households report that climate change is an urgent issue, respectively. In addition, extreme rainfall events, such as increasing rainfall and late rainfall, have influenced the local people's experiences and perceptions of climate-related hazards, which are detailed in Sects. 3.3 and 3.4. Thailand has a typical tropical climate and is hot and humid with small seasonal changes throughout the year. The 
air temperature for the year varies from 21 to $35^{\circ} \mathrm{C}$, while the relative humidity varies from 45 to $95 \%$. Overall, $82 \%$ of households have not perceived any changes in temperature, although the average temperature has risen significantly around the world in recent decades [43]. All of the above perceptions have demonstrated how climate change is experienced on the ground.

Table 1

Fisher's exact test performed between households variables, climate variables, and the climate change perception; and the perceptions of changes in the climate variables and flooding

\begin{tabular}{|c|c|c|c|c|c|}
\hline \multicolumn{3}{|c|}{ Variables } & $\begin{array}{c}\text { Number of respondent } \\
\mathbf{N}(\% \text { of total } 87 \text { households) }\end{array}$ & $\begin{array}{c}\text { Perceived climate change } \\
n(\% \text { of } N)\end{array}$ & $p$ value \\
\hline \multirow{6}{*}{$\begin{array}{r}\text { Household } \\
\text { variables }\end{array}$} & Gender & $\begin{array}{l}\text { Male } \\
\text { Female }\end{array}$ & $\begin{array}{r}36(41.4) \\
51(58.6) \\
\end{array}$ & $\begin{array}{l}32(89) \\
48(94) \\
\end{array}$ & 0.311 \\
\hline & Age & $\begin{array}{l}<=50 \\
>50\end{array}$ & $\begin{array}{l}40(46) \\
47(54)\end{array}$ & $\begin{array}{l}36(90) \\
44(94)\end{array}$ & 0.409 \\
\hline & Education & $\begin{array}{l}\text { Elementary school or less } \\
\text { High school or more }\end{array}$ & $\begin{array}{c}81(93) \\
6(7)\end{array}$ & $\begin{array}{l}75(92) \\
5(83)\end{array}$ & 0.405 \\
\hline & $\begin{array}{r}\text { Income } \\
\text { source }\end{array}$ & $\begin{array}{l}\text { Agriculture } \\
\text { Non-agriculture } \\
\end{array}$ & $\begin{array}{l}76(87) \\
11(13) \\
\end{array}$ & $\begin{array}{l}71(93) \\
9(82) \\
\end{array}$ & 0.214 \\
\hline & $\begin{array}{r}\text { Years of } \\
\text { farming } \\
\text { experience }\end{array}$ & $\begin{array}{l}<=30 \text { years } \\
>30 \text { years }\end{array}$ & $\begin{array}{l}43(49) \\
44(51)\end{array}$ & $\begin{array}{l}39(91) \\
41(93)\end{array}$ & 0.487 \\
\hline & $\begin{array}{r}\text { Irrigation } \\
\text { facility* }\end{array}$ & $\begin{array}{l}\text { Yes } \\
\text { No } \\
\end{array}$ & $\begin{array}{l}25(33) \\
51(67) \\
\end{array}$ & $\begin{array}{l}24(96) \\
47(92) \\
\end{array}$ & 0.465 \\
\hline \multirow{2}{*}{$\begin{array}{r}\text { Climate } \\
\text { variables }\end{array}$} & $\begin{array}{r}\text { Rainfall } \\
\text { timing }\end{array}$ & $\begin{array}{l}\text { Timely rain } \\
\text { Late rain }\end{array}$ & $\begin{array}{l}12(14) \\
75(86)\end{array}$ & $\begin{array}{c}8(67) \\
72(96)\end{array}$ & $0.006 * *$ \\
\hline & $\begin{array}{c}\text { Rainfall } \\
\text { amount }\end{array}$ & $\begin{array}{l}\text { Change (increase/decrease) } \\
\text { No change }\end{array}$ & $\begin{array}{l}65(75) \\
22(25)\end{array}$ & $\begin{array}{c}58(89) \\
22(100)\end{array}$ & 0.617 \\
\hline $\begin{array}{l}\text { Climate } \\
\text { variable }\end{array}$ & $\begin{array}{r}\text { Perceived heav } \\
\text { rainfa }\end{array}$ & $\begin{array}{ll}y y & \text { Yes } \\
\text { all } & \text { No }\end{array}$ & $\begin{array}{c}80(92) \\
7(8)\end{array}$ & $\begin{array}{l}21(26) \\
5(71)\end{array}$ & $0.023 * *$ \\
\hline
\end{tabular}

Note: *- only 65 farming households are considered for this particular test, $* * p \leq 0.05$ - statistically significant at the $95 \%$ confidence level and data for perceived increasing trend in flood events $\mathrm{n}(\%$ of $\mathrm{N})$ is shaded grey.

\subsection{Scientific observations of climate change}

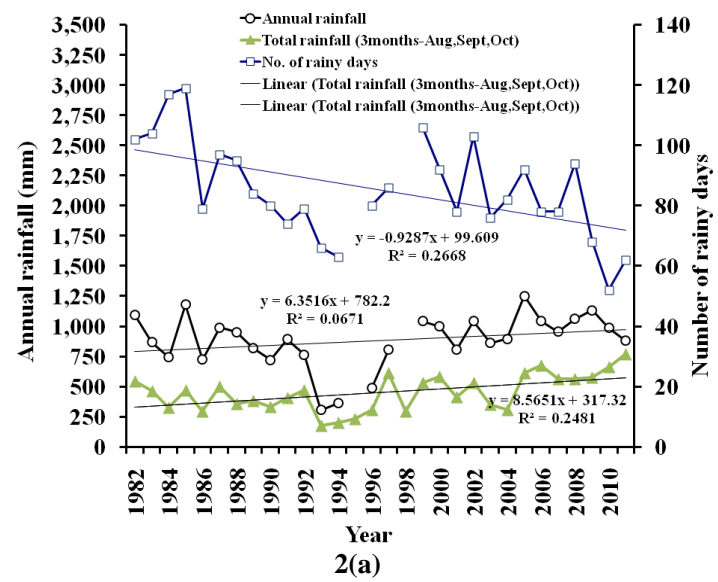

Fig. 2a. Trends of annual rainfall, the number of rainy days and the total rainfall during the peak rainy months (August, September and October) for 30 years at the rainfall station-07152 (Note: data were missing for 1995 and 1998)

An analysis of 30 years of annual rainfall data from the nearest Mae Chaem station provides evidence of climate change in the study area. These data show that a radical change in rainfall occurred in 1993. After 1993, the rainfall showed an increasing trend for 18 years. However, the number of rainy days decreased (Fig. 2a). In addition, a study by Wilk et al. [44] supports this claim regarding the decreasing number of rainy days in northern Thailand. In addition, this analysis demonstrates high accumulated monthly rainfall values that were greater than the 30 year mean value for 2000, and 2002 through 2011 (Fig. 2b). However, it also shows some years when little accumulated rainfall $(<600 \mathrm{~mm})$ had occurred by October and local people had to supplement irrigation using water from reservoir. However, it was only feasible in limited areas and many farmers incurred production loss. A study by Kuraji et al. [45, 46] identified altitudinal increases in rainfall duration and frequency in the MCB. Furthermore, data from the Mae Chaem station showed extreme rainfall delays in 2010 and 2011. Regarding temperature changes, the average-, maximum-, and minimum- temperature anomalies that were plotted using 57 years of data from 45 rainfall stations across Thailand (Fig. 3a to 3c) showed an increasing trend following 1990 [38]. Furthermore, a study by 
Limasakul and Goes [47] indicated an increasing trend in surface air temperature in Thailand. Specifically, the minimum temperature increased at a faster rate than the maximum temperature after the early 1950s. A comparison of the local people's perceptions of scientific observations of the rainfall and temperature changes revealed that the households in the YLV correctly perceived rainfall changes and are aware of climate change. However, they have not perceived any changes in temperature.
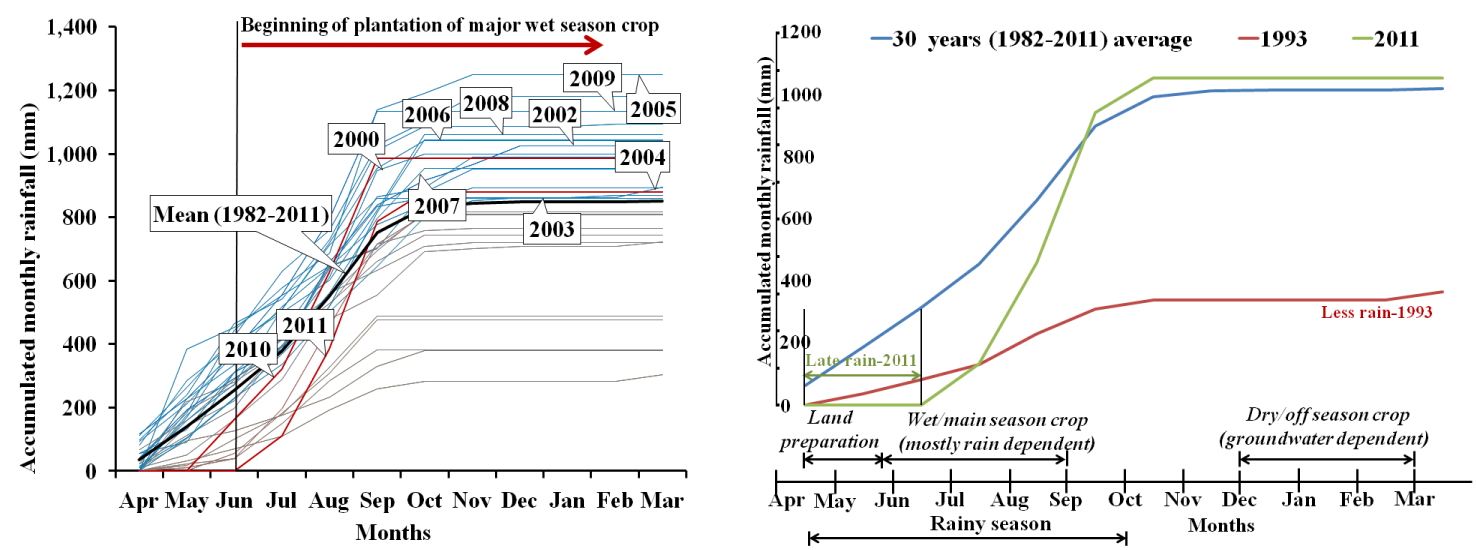

2(b)

Fig. 2b. Accumulated monthly rainfall for 30 years and extremely late and less rainfall years at the rainfall station-07152
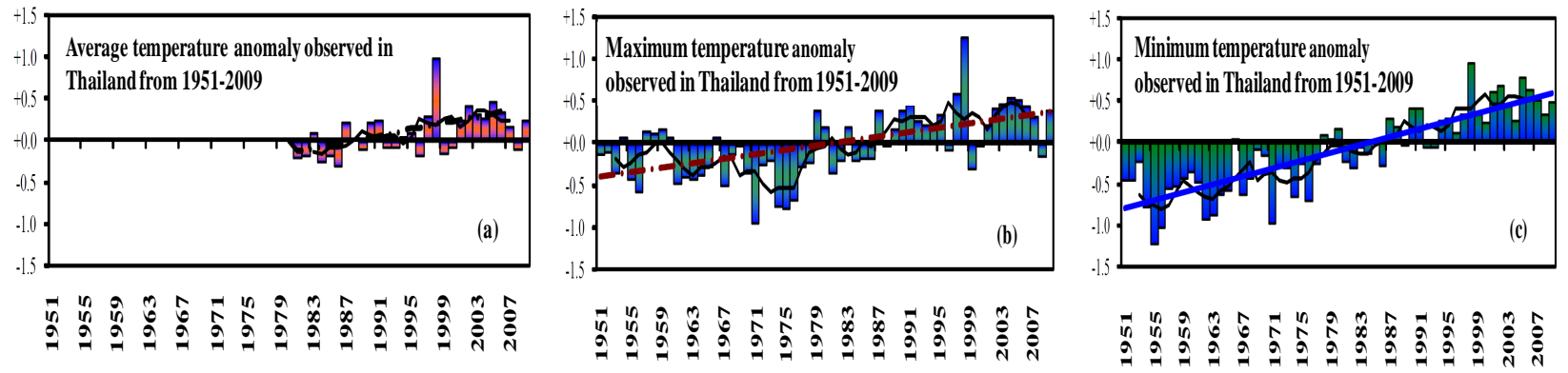

Fig. 3. Average (a), maximum (b), and minimum temperature (c) anomalies and trends plotted using 57 years of data from 45 stations across Thailand [38]

\subsection{Perceptions of the local people regarding climate-related hazards}

Local people have perceived droughts, floods, and landslides as major hazards related to climate change (mainly rainfall changes), which are causing social disruption and economic hardships in YLV. Information regarding these hazards is very important. Understanding the physical situation, the local people's perception of climate-related hazards and their impacts can help natural resource managers and policymakers plan measures for minimizing the most severe impacts in the future. The local people's perceptions of climate-related hazards and their impacts are presented below.

\subsubsection{Local people's perceptions of drought}

The dry season is a common natural phenomenon in the YLV that occurs every year between November and April. However, $77 \%$ of households have perceived an increase in the severity of dry conditions in recent decades, which they reported as drought. These households have perceived drought as a period with less, late or no rainfall. Overall, 48 and $47 \%$ of households have identified the decreasing number of rainy days and late rainfall as major causes of drought. The drought events that the households recalled were those of 1998, 2000, 2002, 2009, 2010 and 2012. The perception of changes regarding the number of rainy days and the rainfall timing was found to significantly affect the perception of an increasing frequency of drought (Table 2). Those who have perceived a decrease in the number of rainy days and late rainfall are most likely to perceive an increase in the frequency of drought. 
Local people have experienced various impacts of drought (Fig. 4). Nearly $75 \%$ of households have observed decreasing surface water resources (mainly declining water levels in the MRR and Mae Ta reservoir). Furthermore, $33 \%$ of households have reported decreasing water level in groundwater wells. Reduction in both surface and groundwater has affected their irrigation and household water use. In addition, 70\% of studied households have perceived that a lack of water storage reservoirs for storing water during the rainy season has further intensified the water problems. Furthermore, drought has serious economic impacts on local livelihood because it affects agriculture, the main economic activity of residents in the YLV. Almost $90 \%$ of households indicated that drought resulted in crop failure, decreased the production of cereal and horticultural crops, increased unemployment, and weakened their income. Approximately $70 \%$ of households have reported a decrease in the optimum growing period of rice (from June to September to July to September) due to late rainfall and partial production loss. However, it is difficult to quantify the impacts of drought on rice production due to the lack of local scale data. The population record from the Department of Provincial Administration [48] shows a gradual yearly increase in the population of YLV. When coupled with increasing population, increasing drought may further exacerbate the drought risk and water problems in the future, which concerns most households. These findings suggest that the construction of ponds/reservoirs to collect rainwater is one desirable solution to drought in YLV, for which the local people expects initial support from the government for its construction and later community support for its operation and management.

Table 2

Multinomial logistic regression for the perception of changes in the frequency of droughts and landslides for the reference category with no differences in drought and landslide frequency

\begin{tabular}{|c|c|c|c|}
\hline Variables & Logistic regression coefficient $(B)$ & $p$ value & Odds ratio \\
\hline \multicolumn{4}{|c|}{ Increasing frequency of drought vs. no difference } \\
\hline Number of rainy days (normal vs. fewer rainy days) & -1.030 & $0.025^{* *}$ & 0.357 \\
\hline Rainfall timing (timely rainfall vs. late rainfall) & -1.378 & $0.004 * *$ & 0.252 \\
\hline \multicolumn{4}{|c|}{ Decreasing frequency of drought vs. no difference } \\
\hline Number of rainy days (normal vs. fewer rainy days) & -1.386 & 0.277 & 0.250 \\
\hline Rainfall timing (timely rainfall vs. late rainfall) & -1.649 & 0.198 & 0.192 \\
\hline \multicolumn{4}{|c|}{ Increasing frequency of landslide vs. no difference } \\
\hline Amount of rainfall (normal vs. heavy rainfall) & -0.294 & 0.556 & 0.745 \\
\hline \multicolumn{4}{|c|}{ Decreasing frequency of landslide vs. no difference } \\
\hline Amount of rainfall (normal vs. heavy rainfall) & -1.393 & $0.031 * *$ & 0.248 \\
\hline
\end{tabular}

\subsubsection{Local people's perceptions of flooding}

Households in YLV have simply perceived floods as the presence of too much water in their surrounding area. Overall, $84 \%$ of the households have experienced floods. In addition, $92 \%$ of the households understand that heavy (high amount) rainfall near the headwaters of the MCR and MRR result in increasing water levels downstream of MCR and its backflow causes flooding in their village. From these observations, the confluence point of the MRR and MCR is narrow relative to the total area and the contributions of water from the MRB, which is conducive for river overflow and flooding in YLV. The smaller $p$ value (0.023) for the Fisher's exact test that was performed between the households perceiving heavy rainfall and increasing trends in flood events (Table 1) indicated that the null hypothesis must be rejected. This result confirms that the households perceiving heavy rainfall have perceived increasing flood trends. The understanding of floods due to heavy rainfall was more developed than the understanding of landslides and the unintentional damming of rivers, which is common in mountainous areas. This finding potentially occurred because the key physical processes for the earlier types of floods are easier for the local people to recognize and understand than later ones related to landslide events. To manage water resources, YLV has a weir (Meung Lum) (Fig. 1c). However, from the field observations, it is clear that the flooding in the village is also a combined effect of stream channel blockage due to landslides and flash floods in the MRR. Therefore, the villager's efforts towards flood mitigation alone cannot lead to effective results without considering landslide mitigation measures.

The studied households reported major flood experiences in 2002, 2003, 2004, 2005, and 2011, but were unable to compare the excessive and destructive flood in 2011 with the earlier events. Regarding the duration and heights of past floods, the households indicated that floods lasted from 1 to 6 days and were $50 \mathrm{~cm}$ to $3 \mathrm{~m}$ high at different locations. These households experienced various impacts from the past flood events (see Fig. 4). For example, 80\% of respondents complained that flooding inhibited regular activity and resulted in the dysfunction of normal life for a 314 period that extended beyond the duration of the event. Approximately 57\% of households faced difficulties when 
collecting groundwater for household use and 79\% reported damage to their assets (e.g., house and farm-related machineries). Agricultural land is often the receptor of flooding. Overall, $84 \%$ of households complained about collapsing irrigation canals and 53\% reported soil erosion (for both farmland and riverbanks). Our field observation as well as study by Thanapakpawin et al. [49] found sandy clay loam and clay loam as prevalent soil texture in the study area. Those textures were more conducive for soil erosion during flooding. Approximately 58 and $64 \%$ of the households faced partial crop losses or a reduction in household income, respectively. Moreover, 30\% of the households living near the MRR have perceived the increasing risk of flooding in the last decade, but have continued to live there. Their decision to remain is undoubtedly influenced by their occupation, especially for subsistence farmers. These farmers perceive the study area as home and have a real or perceived lack of alternatives. The provision of good drainage, channel capacity improvement and landslide prevention through afforestation are some potential mitigation measures that could be used for YLV.

\subsubsection{Local people's perceptions of landslides}

Households in YLV have perceived landslide as the large movement of land. Rainfall, deforestation and farming on slopes were identified as the various causes of landslide. The majority (69\% of households) of households perceived rainfall as the principal trigger of landslides. Nearly $40 \%$ of households have experienced landslides in the last two decades and reported major landslide events in 2002, 2003, and 2004. Among these landslide events, the households remember the 2002 landslide as the most disastrous. Fortunately, this landslide did not claim any life. However, it completely destroyed one hundred and eighty houses and disrupted the functions of the village. In addition, approximately 59, 49 and $21 \%$ of households reported asset loss, blockage of roads and the destruction of irrigation canals as the major effects of landslides (Fig. 4). Overall, the 2002 landslide resulted in severe socio-economic consequences. Around sixty households were relocated to a new area (see Fig. 1c). However, some households were reluctant to move; thus, they remained at the same location because the new area is far from their farmlands and did not have reliable water sources.

The perceptions of the changes in the amounts of rainfall were found to significantly influence the perception of a decreasing frequency of landslide (Table 2). Although $61 \%$ of households perceived increasing rainfall in the last two decades, they were the most likely to perceive a decreasing frequency of landslides. This perception possibly occurred because the households have not experienced any landslide disasters since 2004. However, a study by Kuraji et al. [46] found altitudinal increases in the rainfall duration and frequency in the MCB. Furthermore, the Department of Water Resources [50] showed an increasing trend in soil moisture in northern Thailand. Both increasing rainfall and soil moisture are conducive for landslides [51]. A study by Petley [4] has found evidences for an increasing trend in fatal landslides in Asia. In addition, Fowze et al. [5] reported that the frequency of raintriggered landslides in Thailand has increased. This information supports the possibility of increasing landslide frequency and the associated risks of landslides in YLV in the future. However, the households have not perceived seriousness of potential landslides. This finding reveals the importance of including local people in studies when determining how climate change may place them at greater risk of landslides and help them in developing mitigation strategies. Moreover, a landslide risk management strategy without waiting for proof of a trend coming from reviews of the climate science is essential.

\subsection{Scientific observation of climate-related hazards}




\subsubsection{Drought}

The analysis of rainfall data from the Mae Chaem station showed a decreasing trend in the number of rainy days from 1982 to 2011 (Fig. 2a), and extremely late rainfall in 2010 and 2011(mid-April to mid-May and mid-June) (Fig. 2b). These observations indicate a match between the local people's perception of drought due to a decreasing number of rainy days and late rainfall. Furthermore, local people have also perceived decreasing trend in the number of rainy days and extremely late rainfall as major causes of decreasing water availability in the MRR and Mae Ta reservoir. However, the data from Mae Chaem station do not imply less rainfall (amount) in the perceived drought years (1998, 2000, 2002, and 2011) (see Fig. 2b). Water availability in the MRR and Mae Ta reservoir is largely controlled by the rainfall upstream of the MRB. Multi-temporal SPI analysis using the precipitation data from the KL station (upstream of MRB) indicated low SPI values $(\leq-1.0)$ for the perceived drought years $(1998,2000$ and 2002) (see Fig. 5a). It supports that the droughts and decreasing water availability in the MRR and Mae Ta reservoir in 1998, 2000 and 2002 resulted from less rainfall in the upstream region of the basin. This finding confirms that the local people have perceived drought but have not correctly perceived the exact cause of decreasing water availability in the nearby water sources. Without understanding the hydrological characteristics and drought phenomenon, the mitigation plans cannot lead to effective results. Thus, these findings are useful for supporting decision makers for drought mitigation and water resource management in YLV.

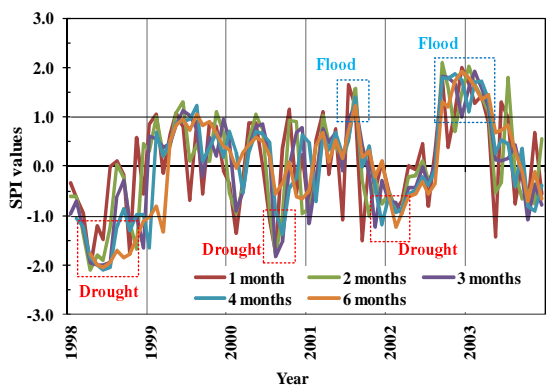

(a)

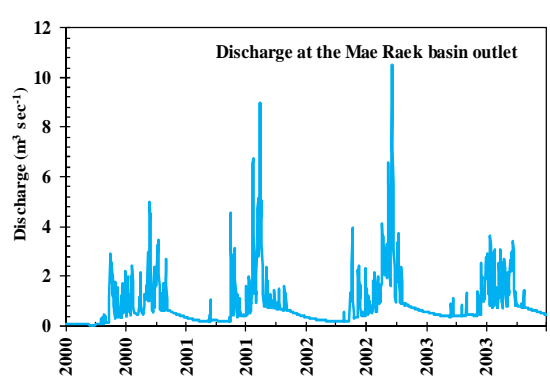

(b)

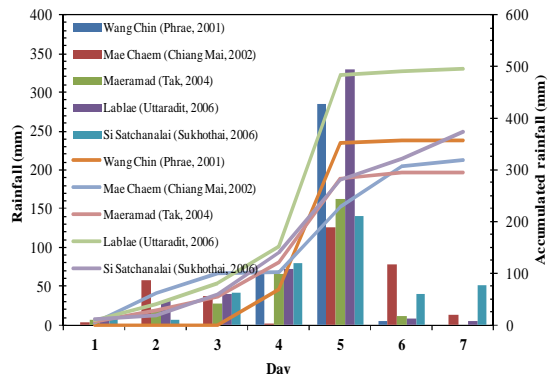

(c)

Fig. 5. Standardized Precipitation Index calculated using 6 years of data from the Mae Klang station in the Mae Raek Basin (MRB) (a); Discharge at the MRB outlet (b); Rainfall (daily and cumulative) records from different rainfall stations in the Upper Chao Phraya Basin during the landslide events in the respective areas (c)

\subsubsection{Flood}

The river discharge simulated at the MRB outlet using the tank model indicated a high discharge in July 2001 and 2002 (Fig. 5b). In addition, the multi-temporal SPI analysis using the precipitation data from the KL station (upstream of the MRB) estimated high rainfall (SPI $\geq 1.0$ ) in 2001 and 2002 (Fig. 5a). Furthermore, an analysis of the rainfall data from the Mae Chaem station demonstrated an increasing trend in annual- and total-rainfall during the peak rainy months (August to October) in the last 30 years (Fig. 2b). These results correspond with the local people's perceptions of flooding due to increasing rainfall. However, as discussed in Sect. 3.3.3, the frequency of rain-triggered landslides has increased in Thailand, which may further increase the damming of rivers and flood hazards in the YLV. This finding supports the need for focusing awareness and adaptation programs towards landslide and flood prevention.

\subsubsection{Landslide}

Department of Mineral Resources (DMR) [11] has reported landslide events in different years and places in northern Thailand, which have included landslides in Phrae (2001), Chiang Mai (2002), Tak (2004), Uttaradit (2006) and Sukhothai (2006), respectively. Fig. 5c shows seven days of rainfall (daily and cumulative) analysis during the landslide events from the different stations (Wang Chin, Mae Chaem, Maeramad, Lablae, Si Satchanalai) near the aforementioned sites. The cumulative rainfall during the 2002 landslide in the YLV (Chiang Mai province) was 300 $\mathrm{mm}$, which was less than in the values at the other three stations. Although the one-day rainfall is not very high (130 $\mathrm{mm}$, just above the rainfall threshold value of $100 \mathrm{~mm}$ in a day that was established by the DMR to trigger landslides), it was sufficient to cause large landslides in YLV. Moreover, earlier rainfall events (prior to one-day rainfall) and high soil moisture also enhance landslide events. This observation and the increasing rainfall observed 
by Kuraji et al. [46] support the increasing probability of landslides and the risks of YLV. A comparison of these scientific observations to the local people's perceptions shows that they correctly perceived landslide events and their causes (heavy rainfall) but not the increasing landslide risk at their location. Hazard awareness campaign, training and early warning system are some important measures for breaking the low perception of potential landslide hazards and protecting from potential disasters in YLV.

\section{Summary and conclusions}

Nearly $45 \%$ of households have perceived climate change personally and $47 \%$ of them have knowledge that climate change is happening through various sources. A significant difference in climate change perception was not observed between the different household variables. However, the perceptions of changes in rainfall timing have significantly affected the perceptions of the local people regarding climate change. This effect occurred because rainfall changes have serious consequences for agriculture and individuals' livelihoods. A comparison of the local people's perceptions to scientific observations shows that 61,82 , and $86 \%$ of households have correctly perceived increasing amounts of rainfall, a decreasing number of rainy days in the last two decades, and extremely late rainfall in recent years, respectively. However, the majority $(82 \%)$ of respondents have not perceived temperature changes.

Furthermore, the results indicated that climate change, particularly rainfall changes, greatly influence the experiences and perceptions of the local people regarding climate-related hazards, such as drought, floods, and landslides. Approximately $77 \%$ of local households have perceived drought but have not correctly perceived its cause. A comparison of the drought perception to rainfall data indicates that the local people are unaware of decreasing rainfall in the upstream areas, which reduced water in the river and causes drought in YLV. Overall, 70\% of households have perceived that a lack of reservoirs for storing water during the rainy season has further intensified the water shortage. The construction of small reservoirs to collect rainwater can be one desirable solution, for which the local people expect initial support from the government for its construction and community support for its operation and management. In addition, 92\% of households perceived that flooding resulted from increasing rainfall around the headwaters of the MCR and MRR. The discharge and rainfall observations agreed well with the local people's perceptions. However, the field observations revealed that flooding also results from stream channel blockage due to landslides and flash floods in the MRR. Furthermore, a scientific study (e.g., Fowze et al. [5]) demonstrated that the frequency of rain-triggered landslides in Thailand is increasing, which may increase the damming of rivers and the flood risks in YLV. The villagers' efforts towards flood mitigation alone cannot lead to effective results without considering landslide mitigation measures. Thus, awareness and adaptation programs should be focused on both landslide and flood mitigation. Additionally, the most disastrous landslide in 2002 mainly shaped the perceptions of the local people regarding landslides. Overall, $61 \%$ of households correctly perceived that landslides occur due to increasing rainfall. However, the respondents were not aware of potential increases in landslide frequency. A hazard awareness campaign should be implemented to correct this low perception of potential landslide risk. Thus, this study provides needed baseline information regarding the local concerns of climate change, climate-related hazards and their interaction with other local dynamics (such as local livelihood) and recommendations on allocation of resources (information, training, adaptation measures, etc.) to help reinforce local adaptation. This kind of information is useful for decision makers who need to understand and facilitate climate change and its related hazard management at a local level in the mountainous areas of northern Thailand as well as other places in different countries.

\section{Acknowledgements}

This study was supported by Grant-in-Aid from the Japan Society for the Promotion of Science (JSPS) Fellows and the Integrated Study Project on Hydro-Meteorological Prediction and Adaptation to Climate Change in Thailand (IMPAC-T Project) funded by the Science and Technology Research Partnership for Sustainable Development, JSTJICA, Japan. In addition, we thank Phonchai Klinkhachorn, Vanvisa Mama, and the staff from RID, Thailand, for helping us conduct the field survey.

\section{References}

[1] Kiehl J. Lessons from the earth's past. Science 2011;331:158-159.

[2] Information from Paleoclimate Archives. In: Masson-Delmotte V, Schulz M, et al. In: Stocker TF, Qin D, Plattner GK, et al., editors. Climate Change 2013: The Physical Science Basis Contribution of Working Group I to the Fifth Assessment Report of the Intergovernmental Panel on Climate Change. Cambridge, UK: Cambridge University Press; 2013.

[3] Petley D. Global patterns of loss of life from landslides. Geology 2012; Doi: 10.1130/G33217.1. 
[4] IPCC. In: Field CB, Barros V, Stocker TF, Qin D, Dokken DJ, Ebi KL, Mastrandrea MD, Mach KJ, Plattner GK, Allen SK, Tignor M, and Midgley PM, editors. Managing the Risks of Extreme Events and Disasters to Advance Climate Change Adaptation. A Special Report of Working Groups I and II of the Intergovernmental Panel on Climate Change. Cambridge, UK: Cambridge University Press; 2012.

[5] Fowze JSM, Bergado DT, Soralump S, Voottipreux P, Dechasakulsom M. Rain-triggered landslide hazards and mitigation measures in Thailand: From research to practice. Geotext Geomembr 2012;30:50-64.

[6] Boonpragob K. Crisis or Opportunity: Climate Change Impacts and Thailand. Thailand: Greenpeace Southeast Asia; 2005.

[7] Jesdapipat S. Thailand Country Report-A Regional Review on the Economics of Climate Change in Southeast Asia. Report submitted for RETA 6427: A Regional Review of the Economics of Climate Change in Southeast Asia. Manila: Asian Development Bank; 2008.

[8] Ono K, Kawagoe S, Kazama S. Analysis of the risk distribution of slope failure in Thailand by the use of GIS data. In: Environmental Hydraulics, Christodoulou G, Stamou AI, editors. London:Taylor \& Francis Group 2010;1189-1194.

[9] Asian Disaster Preparedness Center. Rapid Assessment: Flashflood and Landslide Disaster in the Provinces of Uttaradit and Sukothai, Northern Thailand. Bangkok, Thailand: Asian Disaster Preparedness Center Report; 2006.

[10] Tantiwanit W. Role of remote sensing in landslide mitigation in Thailand. In: Proceedings of Seminar on International Geohazards Week. Bangkok, Thailand; 2007.

[11] Department of Mineral Resources. Landslide statistics. [Online]. Available:<http://www.dmr.go.th/ewt_news.php?nid=6840\&>; 2014 (in Thai). [accessed August 2014 ].

[12] Thai Meteorological Department. Average-, maximum-, and minimum-temperature anomalies and trends plotted using 57 years data from 45 stations over Thailand. [Online]. Available:<www.tmd.go.th/NCCT/climate_change.php.>; 2014 (in Thai). [accessed August 2014].

[13] Komori D, Nakamura S, Kiguchi M, Nishijima A, Yamazaki D, Suzuki S, Kawasaki A, Oki K, Oki T. Characteristics of the 2011 Chao Phraya River flood in Central Thailand. Hydrol Res Lett 2012;6:41-46.

[14] Champathong A, Komori D, Kiguchi M, Sukhapunnaphan T, Oki T, Nakaegawa T. Future Projection of mean river discharge climatology for the Chao Phraya River basin. Hydrol Res Lett 2013;7(2):36-41.

[15] Kotsuki S, Tanaka K, Watanabe S. Projected hydrological changes and their consistency under future climate in the Chao Phraya River Basin using multi-model and multi-scenario of CMIP5 dataset. Hydrol Res Lett 2014;8(1):27-32.

[16] Walther G, Post E, Convey P, et al. Ecological responses to recent climate change. Nature 2002;416:389-395.

[17] Bärring L, Persson G. Influence of climate change on natural hazards in Europe. In: Schmidt-Thomé P editor. Natural and Technological Hazards and Risks Affecting the Spatial Development of European Regions. Geological Survey of Finland, Special Paper 2006;42:93-107.

[18] Hartter J, Stampone MD, Ryan SJ, Kirner K, Chapman CA, Goldman A. Patterns and perceptions of climate change in a biodiversity conservation hotspot. PLoS ONE 2012;7(2):e32408.

[19] Laidler GJ. Inuit and scientific perspectives on the relationship between sea ice and climate change: the ideal complement? Clim Chang 2006;78:407-444.

[20] Danielsen F, Burgess ND, Balmford A. Monitoring matters: examining the potential of locally-based approaches. Biodivers Conserv 2005; 14:2507-2542.

[21] Hung HV, Shaw R, Kobayashi M. Flood risk management for the RUA of Hanoi, Importance of community perception of catastrophic flood risk in disaster risk planning. Disaster Prev Manage 2007;16(2):245-258.

[22] Bradford RA, O'Sullivan JJ, van der Craats IM, et al. Risk perception - issues for flood managements in Europe. Nat Hazards Earth Syst Sci 2012;12:2299-2309.

[23] Manandhar S, Vogt DS, Perret SR, Kazama F. Adapting cropping systems to climate change in Nepal: a cross-regional study of farmers' perception and practices. Reg Environ Change 2011;11:335-348.

[24] Sudmeier-Rieux K, Jaquet S, Derron M, Jaboyedoff M. A case study of coping strategies and landslides in two villages of Central-Eastern Nepal. Appl Geogr 2012;32:680-690.

[25] Deng M, Qin D, Zhang H. Public perceptions of climate and cryosphere change in typical arid inland river areas of China: Facts, impacts and selections of adaptation measures. Quat Int 2012;282:48-57.

[26] Manandhar S, Pandey VP, Kazama F. Hydro-climatic trends and people's perceptions: case of Kali Gandaki River Basin, Nepal. Clim Res 2012;54:167-179.

[27] Manandhar S, Pandey VP, Kazama F. Climate change and adaptation: an integrated framework linking social and physical aspects in poorlygauged regions. Clim Chang 2013;120:727-739.

[28] Gautam A, Shivakoti GP. Evolution and impacts of community based forest management in the hills of Nepal. Thailand:Asian Institute of Technology; 2001.

[29] Kuraji K, Punyatrong K, Sirisaiyard I. GAME-T Rainfall measurement in the Mae Chaem Watershed Data Archive. [Online] Available: <http://www.uf.a.u-tokyo.ac.jp/ kuraji/MaeChaem/>; 2014 [accessed August 2014 ].

[30] Royal Irrigation Department. Daily time series of precipitation from various meteorological stations. Bangkok, Thailand; 2011.

[31] Acock AC. Working with missing values. J Marriage Fam 2005;67:1012-1028.

[32] Brouder P, Lundmark L. Climate change in Northern Sweden: Intra-regional perceptions of vulnerability among winter-oriented tourism businesses. J Sustainable Tour 2011;19(8):919-933.

[33] Gebrehiwot T, Veen A. Farm Level Adaptation to Climate Change: The case of Farmer's in the Ethiopian Highlands. Environ Manage 2013; 52:29-44.

[34] Raymond CM, Spoehr J. The acceptability of climate change in agricultural communities: Comparing responses across variability and change. J Environ Manage 2013;115:69-77.

[35] Habiba U, Shaw R, Takeuchi Y. Farmer's perception and adaptation practices to cope with drought: Perspectives from Northwestern Bangladesh. IJDRR 2012;1:72-84.

[36] Combest-Friedman C, Christie P, Miles E. Household perceptions of coastal hazards and climate change in the Central Philippines. J Environ Manage 2012;112:137-148.

[37] McKee TB, Doesken NJ, Kleist J. The relationship of drought frequency and duration to time scales. In: $8^{\text {th }}$ Conference on Applied Climatology. Boston:Meteor. Soc.; 1993.

[38] Thai Meteorological Department. Drought (in Thai). [Online] Available: <http://www.tmd.go.th/info/info.php?FileID=71.>; 2014 [accessed July 2014 ].

[39] Sugawara M. Method of Runoff Analysis. Tokyo, Japan: Kyoritsu Pub (in Japanese); 1972.

[40] Yokoo Y, Kazama S, Sawamoto M, Nishimura H. Regionalization of lumped wáter balance model parameters based on multiple regression. J Hydrol 2001;246:209-222. 
[41] Yokoo Y, Kazama S. Numerical investigations on the relationships between watershed characteristics and water balance model parameters: searching for universal relationships among regional relationships. Hydrol Process 2012; 26:843-854.

[42] Meze-Hausken E. Contrasting climate variability and meteorological drought with perceived drought and climate change in northern Ethiopia. Clim Res 2004;27:19-31.

[43] Summary for Policymakers. In: Stocker TF, Qin D, Plattner GK, Tignor M, Allen SK, Boschung J, Nauels A, Xia Y, Bex V and Midgley PM, editors. Climate Change 2013: The Physical Science Basis. Contribution of Working Group I to the Fifth Assessment Report of the Intergovernmental Panel on Climate Change. Cambridge, UK: Cambridge University Press; 2013.

[44] Wilk J, Andersson L, Plermkamon V. Hydrological impacts of forest conversion to agriculture in a large river basin in northeast Thailand. Hydrol Process 2001;15(14):2729-2748.

[45] Kuraji K, Kowit P, Masakazu S. Altitudial increase in rainfall in Mae Chaem watershed, Thailand. J Meteor Soc Japan 2001;1B:353-363.

[46] Kuraji K, Mie G, Kowit P. Inter-annual and spatial variation of altitudinal increase in rainfall over Mount Inthanon and Mae Chaem Watershed, Northern Thailand. Hydrol Res Lett 2009;3:18-21

[47] Limsakul A, Goes JI. Empirical evidence for interannual and longer period variability in Thailand surface air temperatures. Atmos Res 2008; $87: 89-102$

[48] Department of Provincial Administration. Population data of Thailand. [Online] Available: <http://stat.dopa.go.th/xstat/popyear.html.>; 2013 [accessed December 2013].

[49] Thanapakpawin P, Richey J, Thomas D, Rodda S, Campbell B, Logsdon M. Effects of landuse change on the hydrologic regime of the Mae Chaem river basin, NW Thailand. J Hydrol 2006;334:215-230.

[50] Department of Water Resources. The study, design, and installation of early warning system for flood and landslide. Bangkok: Department of Water Resources; 2008.

[51] Ono K, Akimoto T, Gunawardhana LN, Kazama S, Kawagoe S. Distributed specific sediment yield estimations in Japan attributed to extreme-rainfall-induced slope failures under a changing climate. Hydrol Earth Syst Sci 2011;15:197-207 